Floresta e Ambiente 2020; 27(3): e20171052

https://doi.org/10.1590/2179-8087.105217

ISSN 2179-8087 (online)

ORIGINAL ARTICLE - Silviculture

Floresta e Ambiente

\title{
Substrates and Container Size on Quality of Peltophorum dubium Seedlings
}

\author{
Rodrigo Ferreira da Silva ${ }^{1}$ (1) 0000-0002-1747-2149 \\ Rudinei De Marco $^{1}$ (D) 0000-0003-2648-0279 \\ Paola Daiane Welter ${ }^{1}$ (D) 0000-0001-6778-993X \\ Patricia Viel ${ }^{1}$ (1) 0000-0001-7091-9088 \\ Clovis Orlando da Ros ${ }^{1}$ [1] 0000-0003-4514-8992
}

\begin{abstract}
This study aims to evaluate the effect of substrates and container content on growth and quality of Peltophorum dubium seedlings. The design was completely randomized in a factorial arrangement $(2 \times 9)$, with two containers sizes $\left(125 \mathrm{~cm}^{3}\right.$ and $\left.280 \mathrm{~cm}^{3}\right)$ and nine substrates formulated from the mixture of subsoil (S), vermicompost (V) and commercial substrate (CS), in the following proportions (v:v): $\mathrm{S}_{100}, \mathrm{~V}_{100}, \mathrm{CS}_{100}, \mathrm{~S}_{75}+\mathrm{V}_{25}, \mathrm{~S}_{50}+\mathrm{V}_{50}, \mathrm{~S}_{25}+\mathrm{V}_{75}$, $\mathrm{CS}_{75}+\mathrm{V}_{25}, \mathrm{CS}_{50}+\mathrm{V}_{50}$ and $\mathrm{CS}_{25}+\mathrm{V}_{75}$, with nine replicates. We assessed seedling height, stem diameter, root and shoot dry matter, height/shoot dry matter ratio; Dickson quality index; and percentages of nitrogen, phosphorous and potassium in the shoot. The use of the $125 \mathrm{~cm}^{3}$ dibble tube containing $100 \%$ vermicompost allowed for higher quality of Peltophorum dubium seedlings.
\end{abstract}

Keywords: native species, vermicompost, commercial substrate.

\section{INTRODUCTION AND OBJECTIVES}

The production of seedlings of native tree species has been studied with greater emphasis in recent years. In the last decades, the forestry sector has been highly profitable in several countries (Basso et al., 2011). In Brazil, this increase stems from the demand for native species to fulfill the set of protectionist measures contained in Law No. 12,651, of May 25, 2012 (Brasil, 2012). Therefore, seedling quality is crucial to establish plantation forests (Trigueiro \& Guerrini, 2014).

One of the promising native species for forest recovery is Peltophorum dubium (Spreng.) Taub. (canafistula), a legume with wide geographic distribution, and undemanding in fertility and soil moisture, potentially associated with atmospheric nitrogen-fixing bacteria, which improves and recovers soil fertility (Carvalho, 2003). According to Carvalho (2003) and Vivian et al. (2010), this is a fast-growing tree species, and it can be used to reforest degraded areas, landscaping, civil construction and carpentry.

Although in recent years information available on the production of seedlings of native tree species for many species has increased, the ideal conditions for their initial growth are not known yet. Therefore, it is important the substrates composition to present appropriate physical and chemical properties to seedling growth while they remain in the nursery (Ferreira et al., 2014).

The size of containers in use also affects the quality of seedlings of tree species. For Lisboa et al. (2012), to identify the most appropriate size of dibble tubes for each species is important because larger dibble tubes take more space in the nursery and require more substrate, which may increase the seedlings final cost. On the other hand, small sizes may result in lower availability of water and nutrients, thus hindering seedling development.

Thus, this study aimed to evaluate the effects of substrates and container size on growth and seedling quality of Peltophorum dubium.

\section{MATERIALS AND METHODS}

The study was conducted in a greenhouse at Universidade Federal de Santa Maria, Frederico Westphalen campus, Rio

\footnotetext{
${ }^{1}$ Universidade Federal de Santa Maria (UFSM), Santa Maria, RS, Brasil
} 
Grande do Sul state, located at latitude $27^{\circ} 21^{\prime}$ ' "South and longitude $53^{\circ} 23^{\prime} 40^{\prime \prime}$ 'West, with an average altitude of $465 \mathrm{~m}$.

The tree species studied was canafistula (Peltophorum dubium), whose seeds were acquired at the Forest Research Center, Fundação Estadual de Pesquisa Agropecuária (FEPAGRO), Santa Maria, Brazil. Before using the seeds in the experiment, they were submitted to dormancy breaking by immersion in hot water at $100^{\circ} \mathrm{C}$, followed by a 24 -hour rest at room temperature. Sowing used three seeds per tube (previously filled with the substrates), for each different size. When they acquired a pair of definitive leaves, the seedlings were thinned; only one seedling was left in each dibble tube, and plant health and vigor were considered to thinning.

To compose each study substrate, the following components were used: commercial substrate (H. DECKER'); subsoil, characterized as a red latosol (Santos et al., 2013), and vermicompost. The soil was collected from a set aside area between the layers at $5 \mathrm{~cm}$ to $20 \mathrm{~cm}$ depth, aiming at eliminating seeds of undesirable plants. The vermicompost was produced from solid cow manure and other organic materials, namely, fruit peels, leaves and grass, which had been decomposed for 120 days. Vermicomposting was performed in polypropylene containers (capacity: $50 \mathrm{~L}$ ), using 1,000 earthworms of the species Eisenia andrei.

The experimental design was completely randomized in a factorial arrangement $(2 \times 9)$ : two sizes of stiff plastic tubes $\left(125 \mathrm{~cm}^{3}\right.$ and $\left.280 \mathrm{~cm}^{3}\right)$ and nine combinations of substrates based on the mixture of subsoil (S), vermicompost (V) and commercial substrate (CS), in the following proportions (v:v): $\mathrm{S}_{100}$ $(100 \% \mathrm{~S}) ; \mathrm{S}_{75}+\mathrm{V}_{25}(75 \% \mathrm{~S}+25 \% \mathrm{~V}) ; \mathrm{S}_{50}+\mathrm{V}_{50}(50 \% \mathrm{~S}+50 \% \mathrm{~V}) ;$ $\mathrm{S}_{25}+\mathrm{V}_{75}(25 \% \mathrm{~S}+75 \% \mathrm{~V}) ; \mathrm{V}_{100}(100 \% \mathrm{~V}) ; \mathrm{CS}_{100}(100 \% \mathrm{CS}) ;$
$\mathrm{CS}_{75}+\mathrm{V}_{25}(75 \% \mathrm{CS}+25 \% \mathrm{~V}) ; \mathrm{CS}_{50}+\mathrm{V}_{50}(50 \% \mathrm{CS}+50 \% \mathrm{~V})$ and $\mathrm{CS}_{25}+\mathrm{V}_{75}(25 \% \mathrm{CS}+75 \% \mathrm{~V})$, with nine replicates.

After producing the definitive substrates, one sample of each substrate was used for chemical characterization. Organic carbon was analyzed by the Walkley-Black method, using samples dried at $65^{\circ} \mathrm{C}$, according to methodology described for chemical analysis of organic fertilizers (Abreu et al., 2009).

$\mathrm{Ca}, \mathrm{Mg}, \mathrm{P}, \mathrm{K}, \mathrm{Cu}$ and $\mathrm{Zn}$ contents available in the soil were quantified by chemical analysis methods to evaluate soil fertility, as described by Silva et al. (2009). Ca, Mg, and Zn were extracted with $\mathrm{KCl}$ solution $1.0 \mathrm{~mol} \mathrm{~L}^{-1}$, and quantified by atomic absorption spectrometry. $\mathrm{P}$ and $\mathrm{K}$ were extracted with solution Mehlich-1 $\left(\mathrm{H}_{2} \mathrm{SO}_{4} 0.0125 \mathrm{~mol} \mathrm{~L}^{-1}+\mathrm{HCl} 0.05 \mathrm{~mol} \mathrm{~L}^{-1}\right.$, and quantified by spectrophotometry with molybdenum blue and by flame photometry, respectively. Table 1 shows the substrates chemical characterization.

Seedling height $(\mathrm{H})$, stem diameter (SD), shoot dry matter (SDM) and root dry matter (RDM) were measured 120 days after sowing. Seedling height was measured from the substrate level to the apex of the main stem with a graduated ruler, while stem diameter was measured with a digital pachymeter (Digimess"). To determine SDM and RDM, the root system was separated from the shoot in the seedling collar region. The root system was flushed with water jets on 1-mm mesh sieves. Subsequently, the shoot and root were dried in a forced air circulation oven at $65^{\circ} \mathrm{C} \pm 1{ }^{\circ} \mathrm{C}$ to constant weight and then weighed on an analytical balance. N, P and $\mathrm{K}$ contents were determined from previously crushed shoot dry matter, according to the chemical analysis methodology for plant tissues, described by Miyazawa et al. (2009).

Table 1. Available nutrient contents, $\mathrm{pH}$ in water (1:1), organic carbon (CO) and base saturation (V) of the substrates.

\begin{tabular}{|c|c|c|c|c|c|c|c|c|c|}
\hline \multirow{2}{*}{ Substrates } & $\mathrm{pH}_{\text {water }}$ & $\mathbf{P}$ & $\mathbf{K}$ & Zn & $\mathrm{Cu}$ & $\mathrm{Ca}$ & $\mathrm{Mg}$ & $\mathrm{CO}$ & $\mathbf{V}$ \\
\hline & $1: 1$ & \multicolumn{4}{|c|}{ 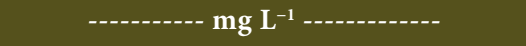 } & \multicolumn{2}{|c|}{$--\mathrm{cmol}_{c} \mathrm{~L}^{-1}--$} & \multicolumn{2}{|c|}{--- \% ---- } \\
\hline$S_{100}$ & 5.2 & 2.7 & 83 & 5.7 & 1.3 & 4.7 & 2.0 & 1.0 & 64.0 \\
\hline $\mathrm{S}_{75}+\mathrm{V}_{25}$ & 6.0 & 16.8 & 468 & 2.6 & 0.7 & 5.5 & 6.8 & 2.9 & 90.0 \\
\hline $\mathrm{S}_{50}+\mathrm{V}_{50}$ & 6.4 & 67.9 & 894 & 1.6 & 0.5 & 8.9 & 11.3 & 3.9 & 93.6 \\
\hline $\mathrm{S}_{25}+\mathrm{V}_{75}$ & 6.5 & 133.4 & 1,518 & 1.2 & 0.3 & 11.8 & 16.1 & 6.6 & 95.5 \\
\hline $\mathrm{V}_{100}$ & 7.2 & 131.7 & 4,278 & 0.1 & 0.1 & 13.9 & 17.2 & 15.4 & 95.4 \\
\hline $\mathrm{CS}_{25}+\mathrm{V}_{75}$ & 6.2 & 259.4 & 1,740 & 0.3 & 0.2 & 24.2 & 16.6 & 22.1 & 94.9 \\
\hline $\mathrm{CS}_{50}+\mathrm{V}_{50}$ & 5.9 & 184.4 & 1,362 & 0.6 & 0.2 & 30.4 & 16.9 & 22.3 & 94.2 \\
\hline $\mathrm{CS}_{75}+\mathrm{V}_{25}$ & 5.7 & 148.5 & 1,116 & 1.1 & 0.3 & 35.8 & 17.6 & 24.0 & 93.2 \\
\hline $\mathrm{CS}_{100}$ & 5.2 & 384.9 & 858 & 1.6 & 0.4 & 37.1 & 17.1 & 32.6 & 92.0 \\
\hline
\end{tabular}

S: subsoil; V: vermicompost; CS: commercial substrate. 
The study morphological parameters were used to calculate the height/shoot dry matter ratio (H/SDM) and the Dickson quality index (DQI), proposed by Dickson et al. (1960), with Equation 1:

$$
\mathrm{DQI}=\frac{\mathrm{TDM}}{\frac{\mathrm{H}}{\mathrm{SD}}+\frac{\mathrm{SDM}}{\mathrm{RDM}}}
$$

DQI: Dickson quality index; TDM: total dry matter; $\mathrm{H}$ : height; SD: stem diameter; SDM: shoot dry matter; RDM: root dry matter.

The parameters were submitted to analysis of variance, and when significant, the means were compared by the Scott-Knott test at $5 \%$ error probability $(p<0.05)$, using statistical software Sisvar (Ferreira, 2016).

\section{RESULTS AND DISCUSSION}

Analysis of variance showed no significant interaction $(p \leq 0.05)$ between container size and substrates for the morphological parameters and quality indexes of Peltophorum dubium seedlings (Tables 2, 3 and 4).

Diameter growth (Table 2) was higher for the seedlings in $280 \mathrm{~cm}^{3}$ dibble tubes. In this size, the combinations $\mathrm{S}_{50}+\mathrm{V}_{50}$ and $\mathrm{S}_{25}+\mathrm{V}_{75}$ were the most prominent ones, providing larger stem diameter. By contrast, $\mathrm{V}_{100}$ provided the highest mean for the $125 \mathrm{~cm}^{3}$ tube (Table 2). The stem diameter is easy to measure, a not destructive method, and also important to estimate the seedling quality standard in nurseries (Gomes et al., 2002). Studying Eucalyptus, Wendling \& Dutra (2010) recommended minimum diameter of $2 \mathrm{~mm}$ to plant seedlings in the field. Thus, although no information is available yet on the minimum value recommended for this morphological parameter in Peltophorum dubium seedlings, this value was achieved, even when using the smallest tube $\left(125 \mathrm{~cm}^{3}\right)$, filled with substrate $\mathrm{V}_{100}$ and $\mathrm{CS}_{50}+\mathrm{V}_{50}$.

Height growth (Table 2) was higher for the seedlings in $125 \mathrm{~cm}^{3}$ dibble tubes, especially in the following the treatments: $\mathrm{V}_{100} ; \mathrm{S}_{75}+\mathrm{V}_{25} ; \mathrm{S}_{50}+\mathrm{V}_{50} ; \mathrm{S}_{25}+\mathrm{V}_{75} ; \mathrm{CS}_{75}+\mathrm{V}_{25}$ and $\mathrm{CS}_{50}+\mathrm{V}_{50}$, which had the highest means. In comparison, the highest means for seedling height were found in the $\mathrm{V}_{100}$ and $\mathrm{CS}_{50}+\mathrm{V}_{50}$ treatments in the $280 \mathrm{~cm}^{3}$ tube (Table 2). Although height is an important variable to characterize seedling quality, the definition of the ideal height for tree species to be planted in the field is still controversial and depends on the planting goal. However, Schorn \& Formento (2003) reported that high-quality seedlings must be between $15 \mathrm{~cm}$ and $20 \mathrm{~cm}$ tall. Therefore, only the $\mathrm{CS}_{100}$ treatment in the $125 \mathrm{~cm}^{3}$ dibble tubes did not meet the quality standard, because the seedlings were $13.43 \mathrm{~cm}$ tall, on average. In comparison, in the $280 \mathrm{~cm}^{3}$ dibble tube, only the $\mathrm{V}_{100}$ and $\mathrm{CS}_{50}+\mathrm{V}_{50}$ treatments resulted in seedlings whose mean heights were within the values suggested by these authors. Therefore, it appears that larger containers are favorable to grow canafístula seedlings, as reported by Danner et al. (2007) in a study with Brazilian grape tree seedlings, combining vermicompost with native forest land. This is because in smaller tubes, seedling density per area is higher in comparison to larger tubes, and competition for light is likely to occur among seedlings; as a result, stems elongate faster through unequal distribution of auxin within plants, directing them towards a source of light (Taiz et al., 2017).

Table 2. Stem diameter and height of Peltophorum dubium seedlings in different substrate combinations.

\begin{tabular}{|c|c|c|c|c|}
\hline \multirow{3}{*}{$\begin{array}{l}\text { Substrate composition } \\
\mathrm{S}_{100}\end{array}$} & \multicolumn{2}{|c|}{ SD $(\mathbf{m m})$} & \multicolumn{2}{|c|}{ Height (cm) } \\
\hline & $125 \mathrm{~cm}^{3}$ & $280 \mathrm{~cm}^{3}$ & $125 \mathrm{~cm}^{3}$ & $280 \mathrm{~cm}^{3}$ \\
\hline & $1.35 \mathrm{cB}^{*}$ & $2.56 \mathrm{eA}$ & $16.89 \mathrm{bA}$ & $10.04 \mathrm{cB}$ \\
\hline $\mathrm{S}_{75}+\mathrm{V}_{25}$ & $1.54 \mathrm{cB}$ & $3.54 \mathrm{cA}$ & $18.40 \quad$ aA & $13.53 \mathrm{bB}$ \\
\hline $\mathrm{S}_{50}+\mathrm{V}_{50}$ & $1.50 \mathrm{cB}$ & $4.49 \mathrm{aA}$ & $20.39 \mathrm{aA}$ & $13.80 \mathrm{bB}$ \\
\hline $\mathrm{S}_{25}+\mathrm{V}_{75}$ & $1.34 \mathrm{cB}$ & $4.37 \mathrm{aA}$ & $19.49 \mathrm{aA}$ & $12.20 \mathrm{bB}$ \\
\hline $\mathrm{V}_{100}$ & $2.56 \mathrm{aB}$ & $3.80 \mathrm{bA}$ & 18.37 aA & $16.00 \mathrm{aB}$ \\
\hline $\mathrm{CS}_{25}+\mathrm{V}_{75}$ & $1.43 \mathrm{cA}$ & $1.70 \mathrm{gA}$ & $16.28 \mathrm{bA}$ & $8.00 \mathrm{~dB}$ \\
\hline $\mathrm{CS}_{50}+\mathrm{V}_{50}$ & $2.26 \mathrm{bB}$ & $3.21 \mathrm{dA}$ & $19.02 \mathrm{aA}$ & $15.43 \mathrm{aB}$ \\
\hline $\mathrm{CS}_{75}+\mathrm{V}_{25}$ & $1.15 \mathrm{~dB}$ & $3.93 \mathrm{bA}$ & $19.27 \mathrm{aA}$ & $13.49 \mathrm{bB}$ \\
\hline $\mathrm{CS}_{100}$ & $0.81 \mathrm{eB}$ & $2.11 \mathrm{fA}$ & $13.43 \mathrm{cA}$ & $8.20 \mathrm{~dB}$ \\
\hline Overall mean & $1.55 \mathrm{~B}$ & $3.3 \mathrm{~A}$ & $17.95 \mathrm{~A}$ & $12.3 \quad \mathrm{~B}$ \\
\hline CV (\%) & & & & \\
\hline
\end{tabular}

${ }^{*}$ Means followed by the same lowercase letter in the column and uppercase in the row do not differ statistically by the Scott-Knott test at 5\% error probability. SD: stem diameter; S: subsoil; V: vermicompost; CS: commercial substrate; CV: coefficient of variation. 
The highest means for shoot dry matter were found in the $\mathrm{V}_{100}$ treatments when using dibble tubes with capacity for $125 \mathrm{~cm}^{3}$ substrate, and in the $\mathrm{V}_{100}$ and $\mathrm{CS}_{100}$ treatments, in $280 \mathrm{~cm}^{3}$ tubes. Except for $\mathrm{CS}_{100}$, the other treatments stimulated the production of shoot dry matter of Peltophorum dubium seedlings in $125 \mathrm{~cm}^{3}$ dibble tubes (Table 3). Previous studies have confirmed that using vermicompost in substrate composition favors the increase of shoot dry matter (Andreazza et al., 2013; Antunes et al., 2016; Steffen et al., 2011; Vieira et al., 2014), hence vermicomposting has great potential to produce seedlings of tree species, because this compound has high nutritional value, as it contains phosphorus, calcium and potassium, among other elements essential to plant growth.

The highest means for root dry matter were found in the $\mathrm{CS}_{100}$ treatments in dibble tubes with $125 \mathrm{~cm}^{3}$ of substrate and in the $\mathrm{V}_{100}$ treatment in the $280 \mathrm{~cm}^{3}$ dibble tubes. The $280 \mathrm{~cm}^{3}$ tube favored the greater growth of the root system of Peltophorum dubium seedlings in different types of substrates, except for the $\mathrm{CS}_{100}$ treatment, in which the higher mean was found in the $125 \mathrm{~cm}^{3}$ dibble tube (Table 3). Antoniazzi et al. (2013) found lower root dry matter in seedlings of Cedrela fissilis (Argentine cedar) in smaller tubes. These results are important, because, according to José et al. (2005), seedlings produced under root restriction conditions undergo a process of hardening, which can develop mechanisms of tolerance to field conditions, and lead to an increase in performance after planting. Thus, limited physical space imposed to the root system of Peltophorum dubium seedlings by the $125 \mathrm{~cm}^{3}$ tube may have favored the production of hardened seedlings.

The lowest mean for the H/SDM ratio (Table 4) was found when using the $125 \mathrm{~cm}^{3}$ tube, except for the $\mathrm{CS}_{100}$ treatment, which was lower in the $280 \mathrm{~cm}^{3}$ tube. For Gomes \& Paiva (2011), the smaller the quotient obtained by dividing height by shoot dry matter production, the more hardened the seedlings, and the higher the field survival index. Thus, the $125 \mathrm{~cm}^{3}$ tube resulted in the production of more hardened seedlings in virtually all the study substrates.

Dickson quality index (DQI) (Table 4) showed highest means in the $125 \mathrm{~cm}^{3}$ tube, and only in $\mathrm{CS}_{100}$, the quality of seedlings was higher when using the $280 \mathrm{~cm}^{3}$ tube of this substrate. Among the study substrates, $\mathrm{V}_{100}$ provided higher-quality seedlings, with DQI of 0.25 and 0.13 , respectively, for the $125 \mathrm{~cm}^{3}$ and $280 \mathrm{~cm}^{3}$ tubes. Vieira et al. (2014) found DQI values between 0.06 and 0.56 for seedlings of Anadenanthera falcata (Benth.) Speg., while Gonzaga et al. (2016) found values ranging from 0.51 to 0.77 for seedlings of courbaril (Hymenaea courbaril L.). In this sense, we can infer that the DQI varies depending on the species, seedling management in the nursery, type and composition of the substrate, container size and, especially, seedling age at the time of assessment (Caldeira et al., 2013). However, according to Faria et al. (2013), the higher the DQI value, the better the seedling quality, which resulted from using the vermicompost in the $125 \mathrm{~cm}^{3}$ dibble tubes, which corroborates the findings for H/SDM.

Table 3. Shoot dry matter and root dry matter of Peltophorum dubium seedlings in different substrate combinations.

\begin{tabular}{|c|c|c|c|c|}
\hline \multirow{3}{*}{$\begin{array}{l}\text { Substrate composition } \\
\mathrm{S}_{100}\end{array}$} & \multicolumn{2}{|c|}{ SDM $\left(\right.$ g plant $\left.^{-1}\right)$} & \multicolumn{2}{|c|}{ RDM (g plant ${ }^{-1}$ ) } \\
\hline & $125 \mathrm{~cm}^{3}$ & $280 \mathrm{~cm}^{3}$ & $125 \mathrm{~cm}^{3}$ & $280 \mathrm{~cm}^{3}$ \\
\hline & $0.55 \mathrm{fA}^{*}$ & $0.15 \mathrm{~dB}$ & $0.13 \mathrm{gB}$ & $0.28 \mathrm{fA}$ \\
\hline $\mathrm{S}_{75}+\mathrm{V}_{25}$ & $1.79 \mathrm{bA}$ & $0.27 \mathrm{cB}$ & $0.22 \mathrm{fB}$ & $0.61 \mathrm{eA}$ \\
\hline $\mathrm{S}_{50}+\mathrm{V}_{50}$ & $1.36 \mathrm{dA}$ & $0.26 \mathrm{cB}$ & $0.24 \mathrm{fB}$ & $0.86 \mathrm{dA}$ \\
\hline $\mathrm{S}_{25}+\mathrm{V}_{75}$ & $1.07 \mathrm{eA}$ & $0.24 \mathrm{cB}$ & $0.65 \mathrm{~dB}$ & $1.31 \mathrm{cA}$ \\
\hline $\mathrm{V}_{100}$ & $2.42 \mathrm{aA}$ & $0.65 \mathrm{aB}$ & $1.15 \mathrm{bB}$ & $3.12 \mathrm{aA}$ \\
\hline $\mathrm{CS}_{25}+\mathrm{V}_{75}$ & $0.41 \mathrm{gA}$ & $0.16 \mathrm{~dB}$ & $0.10 \mathrm{gA}$ & $0.18 \mathrm{gA}$ \\
\hline $\mathrm{CS}_{50}+\mathrm{V}_{50}$ & $1.40 \mathrm{dA}$ & $0.48 \quad \mathrm{bB}$ & $0.49 \mathrm{eB}$ & $0.78 \mathrm{dA}$ \\
\hline $\mathrm{CS}_{75}+\mathrm{V}_{25}$ & $1.64 \mathrm{cA}$ & $0.34 \mathrm{cB}$ & $0.80 \mathrm{cB}$ & $1.52 \mathrm{bA}$ \\
\hline $\mathrm{CS}_{100}$ & $0.40 \mathrm{gB}$ & $0.71 \quad \mathrm{aA}$ & $1.32 \mathrm{aA}$ & $0.33 \mathrm{fB}$ \\
\hline Overall mean & $1.22 \mathrm{~A}$ & $0.36 \quad \mathrm{~B}$ & $0.57 \quad \mathrm{~B}$ & $1.00 \mathrm{~A}$ \\
\hline CV (\%) & \multicolumn{2}{|c|}{14.5} & \multicolumn{2}{|c|}{16.3} \\
\hline
\end{tabular}

${ }^{*}$ Means followed by the same lowercase letter in the column and uppercase in the row do not differ statistically by the Scott-Knott test at 5\% error probability. SDM: shoot dry matter; RDM: root dry matter; S: subsoil; V: vermicompost; CS: commercial substrate; CV: coefficient of variation. 
Table 4. Height-shoot dry matter ratio and Dickson quality index in Peltophorum dubium seedlings in different substrate combinations.

\begin{tabular}{|c|c|c|c|c|}
\hline \multirow{2}{*}{$\begin{array}{c}\text { Substrate } \\
\text { composition }\end{array}$} & \multicolumn{2}{|c|}{$\mathrm{H} / \mathrm{SDM}$} & \multicolumn{2}{|c|}{ DQI } \\
\hline & $125 \mathrm{~cm}^{3}$ & $280 \mathrm{~cm}^{3}$ & $125 \mathrm{~cm}^{3}$ & $280 \mathrm{~cm}^{3}$ \\
\hline$S_{100}$ & $31.04 \mathrm{bB}^{*}$ & 66.58 aA & $0.02 \mathrm{eA}$ & $0.01 \mathrm{eA}$ \\
\hline $\mathrm{S}_{75}+\mathrm{V}_{25}$ & $10.56 \mathrm{~dB}$ & 50.80 bA & $0.09 \mathrm{bA}$ & $0.02 \mathrm{~dB}$ \\
\hline$S_{50}+V_{50}$ & $15.06 \mathrm{cB}$ & 53.97 bA & $0.06 \mathrm{cA}$ & $0.02 \mathrm{~dB}$ \\
\hline $\mathrm{S}_{25}+\mathrm{V}_{75}$ & $18.50 \mathrm{cB}$ & $50.60 \mathrm{bA}$ & $0.05 \mathrm{cA}$ & $0.03 \mathrm{~dB}$ \\
\hline $\mathrm{V}_{100}$ & $7.64 \mathrm{~dB}$ & $24.70 \quad \mathrm{eA}$ & 0.25 aA & $0.13 \mathrm{aB}$ \\
\hline $\mathrm{CS}_{75}+\mathrm{V}_{25}$ & $11.85 \mathrm{~dB}$ & $39.91 \quad \mathrm{cA}$ & $0.09 \mathrm{bA}$ & $0.04 \mathrm{cB}$ \\
\hline $\mathrm{CS}_{50}+\mathrm{V}_{50}$ & $13.76 \mathrm{cB}$ & $32.48 \mathrm{dA}$ & $0.09 \mathrm{bA}$ & $0.03 \mathrm{cB}$ \\
\hline $\mathrm{CS}_{25}+\mathrm{V}_{75}$ & $40.61 \mathrm{aB}$ & 50.92 bA & $0.01 \mathrm{eA}$ & $0.01 \mathrm{eA}$ \\
\hline $\mathrm{CS}_{100}$ & $33.94 \quad \mathrm{bA}$ & $11.84 \mathrm{fB}$ & $0.03 \mathrm{~dB}$ & $0.07 \mathrm{bA}$ \\
\hline Overall mean & $20.33 \quad$ B & $42.42 \mathrm{~A}$ & $0.08 \mathrm{~A}$ & $0.04 \quad \mathrm{~B}$ \\
\hline CV (\%) & & & & \\
\hline
\end{tabular}

${ }^{*}$ Means followed by the same lowercase letter in the column and uppercase in the row do not differ statistically by the Scott-Knott test at 5\% error probability. H/ SDM: height-shoot dry matter ratio; DQI: Dickson quality index; S: subsoil; V: vermicompost; CS: commercial substrate; CV: coefficient of variation.

No significant interaction occurred between substrates and tube sizes for N, P and K contents in the shoot of Peltophorum dubium seedlings (Table 5). The highest concentrations of $\mathrm{N}$ and $\mathrm{K}$ were obtained in seedlings grown in substrates with $\mathrm{CS}_{25}+\mathrm{V}_{75}$ and $\mathrm{CS}_{50}+\mathrm{V}_{50}$, which probably led to higher shoot growth in these treatments. $\mathrm{N}$ and $\mathrm{K}$ are part of the group of macronutrients and participate in important metabolic functions, specially nitrogen, constituent of structural molecules in plants, which favor growth and development of plants (Taiz et al., 2017).

The highest $\mathrm{P}$ content values were found with $\mathrm{V}_{100}$ and in mixtures with the soil or the commercial substrate (Table 5). Lima et al. (2006) stressed that the highest levels of $\mathrm{P}$ and $\mathrm{K}$ in the stem and leaves of acerola cherry tree (Malphigia emarginata DC.) were found when using vermicompostbased substrates. This finding highlights the quality of the organic compound in the composition of substrates to produce seedling.

Container size does not interfere with $\mathrm{N}, \mathrm{P}$ and $\mathrm{K}$ contents in the shoot of Peltophorum dubium seedlings (Table 5). However, notably, the inappropriate choice of containers may reduce nutrient translocation (Cunha et al., 2005). Plastic containers whose height is greater than their diameter help forest species develop further, depending on the growth potential of their axial roots and, consequently, their secondary roots (Cândido \& Gomes, 1993). Thus, we can infer that although $125 \mathrm{~cm}^{3}$ tubes were smaller, they were long enough, hence they did not impair root growth of Peltophorum dubium seedlings.
In a study with macacaúba (Platymiscium ulei Harms) and itaúba (Mezilaurus itauba (Meisn.) Taub), unlike this study, Ferreira et al. (2017) reported that seedling growth was limited by container size. Most small containers restricted the levels of nutrients for the plants total dry matter. Because of their size, larger containers tend to provide less root restriction (Malavasi \& Malavasi, 2006) and hence they retain more nutrients and water (Gomes et al., 2002). Therefore, they offer more nutrients to plants and consequently help to stimulate their growth and develop further the variables height, stem diameter and total dry matter (Brachtvogel \& Malavasi, 2010).

However, choosing the tube volume is relevant, once larger tubes occupy more space in the nursery and require a greater amount of substrate, which may contribute to increase the final cost of production (Kostopoulou et al., 2011; Lisboa et al., 2012). Thus, the type of substrate associated with small dimensions may result in lower availability of water and nutrients and, consequently, less growth of seedlings.

In general, the use of the tube with $125 \mathrm{~cm}^{3}$ of volumetric capacity and the use of vermicompost as substrate favored the higher growth and quality of the Peltophorum dubium seedlings. Therefore, using vermicompost as a substrate may be an important alternative to produce seedlings of tree species. According to Trazzi et al. (2013), vermicomposting is not only an interesting solution for proper disposal of organic waste but also an effective alternative to reduce the high inputs costs required to produce seedling (Trazzi et al., 2013). 
Table 5. Nitrogen, phosphorus and potassium contents in the shoot of Peltophorum dubium seedlings in the substrate combinations.

\begin{tabular}{|c|c|c|c|}
\hline Substrates/tubes & $\mathrm{N}(\%)$ & $\mathrm{P}(\%)$ & K (\%) \\
\hline \multicolumn{4}{|l|}{ Effect of type of substrate } \\
\hline$S_{100}$ & $1.00 \mathrm{~b}^{*}$ & $0.41 \quad \mathrm{a}$ & $0.91 \mathrm{~b}$ \\
\hline $\mathrm{S}_{75}+\mathrm{V}_{25}$ & $1.06 \mathrm{~b}$ & $0.40 \quad \mathrm{a}$ & $0.99 \mathrm{~b}$ \\
\hline $\mathrm{S}_{50}+\mathrm{V}_{50}$ & $1.02 \mathrm{~b}$ & 0.41 a & $0.92 \mathrm{~b}$ \\
\hline $\mathrm{S}_{25}+\mathrm{V}_{75}$ & $0.97 \mathrm{~b}$ & $0.35 \quad \mathrm{a}$ & $0.92 \mathrm{~b}$ \\
\hline $\mathrm{V}_{100}$ & $1.00 \mathrm{~b}$ & 0.33 a & $0.89 \mathrm{~b}$ \\
\hline $\mathrm{CS}_{25}+\mathrm{V}_{75}$ & $1.42 \mathrm{a}$ & 0.39 a & $1.41 \mathrm{a}$ \\
\hline $\mathrm{CS}_{50}+\mathrm{V}_{50}$ & $1.32 \mathrm{a}$ & $0.40 \quad \mathrm{a}$ & $1.28 \mathrm{a}$ \\
\hline $\mathrm{CS}_{75}+\mathrm{V}_{25}$ & $1.05 \mathrm{~b}$ & 0.43 a & $0.75 \mathrm{c}$ \\
\hline $\mathrm{CS}_{100}$ & $1.02 \mathrm{~b}$ & $0.22 \mathrm{~b}$ & $0.63 \mathrm{c}$ \\
\hline \multicolumn{4}{|l|}{ Effect of dibble tube size } \\
\hline $125 \mathrm{~cm}^{3}$ & $1.05 \mathrm{a}$ & 0.36 a & 0.91 a \\
\hline $280 \mathrm{~cm}^{3}$ & $1.14 \mathrm{a}$ & $0.38 \quad \mathrm{a}$ & $1.02 \mathrm{a}$ \\
\hline CV (\%) & 19.17 & 18.29 & 21.27 \\
\hline
\end{tabular}

${ }^{*}$ Means followed by the same letter in the column do not differ statistically by the Scott-Knott test at $5 \%$ error probability. N: nitrogen; P: phosphorus; K: potassium; S: subsoil; V: vermicompost; CS: commercial substrate; CV: coefficient of variation.

\section{CONCLUSIONS}

The use of the $125 \mathrm{~cm}^{3}$ dibble tube containing $100 \%$ vermicompost allowed for greater growth and quality of Peltophorum dubium seedlings.

\section{ACKNOWLEDGEMENTS}

The authors thank Coordenação de Aperfeiçoamento de Pessoal de Nível Superior (CAPES), for the resources given for this study, and Fundação Estadual de Pesquisa Agropecuária (FEPAGRO), for offering the genetic material.

\section{SUBMISSION STATUS}

Received: 19 Oct. 2017

Accepted: 18 Feb. 2019

Associate editor: José Carlos Arthur Junior

(D) 0000-0002-4161-8822

\section{CORRESPONDENCE TO \\ Paola Daiane Welter}

Universidade Federal de Santa Maria (UFSM), Linha 7 de Setembro, s/n, CEP 98400-000, Frederico Westphalen, RS, Brasil e-mail: pdaianew@hotmail.com

\section{REFERENCES}

Abreu MF, Abreu CHA Jr, Silva FC, Santos GCG, Andrade JC, Gomes $\mathrm{TF}$ et al. Análises químicas de fertilizantes orgânicos (urbanos).
In: Silva FC, editor. Manual de análises químicas de solos, plantas e fertilizantes. Brasília, DF: Embrapa; 2009. p. 397-481.

Andreazza R, Antoniolli ZI, Silva RF, Schirmer GK, Scheid DL, Quadro MS et al. Efeito de vermicomposto no crescimento inicial de ipê amarelo e leucena. Nativa 2013; 1(1): 29-33. 10.14583/23187670.v01n01a06

Antoniazzi AP, Binotto B, Neumann GM, Budke JC, Sausen TL. Eficiência de diferentes recipientes no desenvolvimento de mudas de Cedrela fissilis Vell. (Meliaceae). Revista Brasileira de Biociências 2013; 11(3): 313-317.

Antunes RM, Castilhos RMV, Castilho DD, Andreazza R, Leal OA. Crescimento inicial de acácia-negra com vermicompostos de diferentes resíduos agroindustriais. Ciência Florestal 2016; 26(1): 1-9. $10.5902 / 1980509821060$

Basso VM, Jacovine LAG, Alves RR, Valverde SR, Silva FL, Brianezi D. Avaliação da influência da certificação florestal no cumprimento da legislação ambiental em plantações florestais. Revista Árvore 2011; 35(4): 835-844. 10.1590/S0100-67622011000500009

Brachtvogel EL, Malavasi UC. Volume do recipiente, adubação e sua forma de mistura ao substrato no crescimento inicial de Peltophorum dubium (sprengel) taubert em viveiro. Revista Árvore 2010; 34(2): 223-232. 10.1590/S0100-67622010000200004

Brasil. Lei Federal n. 12.651, de 28 de maio de 2012. Diário Oficial da República Federativa do Brasil (2012 May 28); Sec. 1: 1.

Caldeira MV, Delarmelina WM, Peroni L, Gonçalves EO, Silva AG. Lodo de esgoto e vermiculita na produção de mudas de eucalipto. Pesquisa Agropecuária Tropical 2013; 43(2): 155-163. 10.1590/S198340632013000200002

Cândido JF, Gomes JM. Introdução as novas técnicas na produção de viveiros florestais II. Documento SIF. Viçosa: ISF; 1993.

Carvalho PER. Espécies arbóreas brasileiras. Colombo: Embrapa Florestas; 2003. 
Cunha ACMC, Wendling I, Souza L Jr. Produtividade e sobrevivência de minicepas de Eucalyptus benthamii Maiden et Cambage em sistema de hidroponia e em tubete. Revista Ciência Florestal 2005: 15(3): 307-310. 10.5902/198050981868

Danner MA, Citadin I, Fernandes AA Jr, Assmann AP, Mazaro SM, Sasso SAZ. Formação de jabuticabeira (Plinia sp.) em diferentes substratos e tamanhos de recipientes. Revista Brasileira de Fruticultura 2007; 29(1): 179-182. 10.1590/S0100-29452007000100038

Dickson A, Leaf AL, Hosner JF. Quality appraisal of white spruce and white pine seedling stock in nurseries. Forestry Chronicle 1960; 36(1): 11-13. 10.5558/tfc36010-1

Faria JCT, Caldeira MVW, Delarmelina WM, Gonçalves EO, Lacerda LC. Uso de resíduos orgânicos no crescimento de mudas de Mimosa setosa. Pesquisa Florestal Brasileira 2013; 33(76): 409-418. 10.4336/2013.pfb.33.76.501

Ferreira DF. Sisvar: a computer statistical analysis system. Ciência e Agrotecnologia 2016; 35(6): 1039-1042. 10.1590/S141370542011000600001

Ferreira LL, Almeida AES, Costa LR, Bezerra FMS, Lima LA, Porto VCN. Vermicompostos como substrato na produção de mudas de berinjela (Solanum melongena) e pimentão (Capsicum annumm). Holos 2014; 4: 269-277. 10.15628/holos.2014.1409

Ferreira MS, Santos JZL, Tucci CAF, Costa LV. Crescimento inicial de itaúba e macacaúba em recipientes de diferentes tamanhos. Ciência Florestal 2017; 27(2): 499-508. 10.5902/1980509827731

Gomes JM, Couto L, Leite HG, Xavier A, Garcia SLR. Parâmetros morfológicos na avaliação da qualidade de mudas de Eucalyptus grandis. Revista Árvore 2002; 26(6): 655-664. 10.1590/S010067622002000600002

Gomes JM, Paiva HN. Viveiros florestais: propagação sexuada. Viçosa: UFV; 2011.

Gonzaga LM, Silva SS, Campos AS, Ferreira RP, Campos ANR, Cunha ACMCM. Recipientes e substratos para a produção de mudas de jatobá (Hymenaea courbaril L.). Revista Brasileira de Agropecuária Sustentável 2016; 6(1): 64-73. 10.21206/rbas.v6i1.309

José AC, Davide AC, Oliveira SL. Produção de mudas de aroeira (Schinus terebinthifolius Raddi) para recuperação de áreas degradadas pela mineração de bauxita. Revista Cerne 2005; 11(2): 187-196.

Kämpf AN. Substrato. In: Kämpf AN, editor. Produção comercial de plantas ornamentais. Guaíba: Agropecuária; 2000. p. 45-73.

Kostopoulou P, Radoglou K, Dini Papanastasi O, Adamidou C. Effect of mini-plug container depth on root and shoot growth of four forest tree species during early developmental stages. Turkish Journal of Agriculture and Forestry 2011; 35(4): 379-390. 10.3906/tar-1104-11

Lima RLS, Siqueira DL, Weber OB, Cecon PR. Teores de macronutrientes em mudas de aceroleira (Malpighia emarginata DC.) em função da composição do substrato. Ciência e Agrotecnologia 2006; 30(6): 1110-1115. 10.1590/S1413-70542006000600010
Lisboa AC, Santos PS, Oliveira Neto SN, Castro DN, Abreu AHM. Efeito do volume de tubetes na produção de mudas de Calophyllum brasiliense e Toona ciliata. Revista Árvore 2012; 36(4): 603-609. 10.1590/S0100-67622012000400003

Malavasi UC, Malavasi MM. Efeito do volume do tubete no crescimento inicial de plântulas de Cordia trichotoma (Vell.) Arrab. Ex Steud E Jacaranda micranta Cham. Ciência Florestal 2006; 16(1): 11-16. 10.5902/198050981883

Miyazawa M, Pavan MA, Muraoka T, Carmo CAFS, Melo WJ. Análise química de tecido vegetal. In: Silva FC, editor. Manual de análises químicas de solos, plantas e fertilizantes. 2nd ed. Brasília, DF: Embrapa; 2009. p. 191-233.

Santos HG, Jacomine PKT, Anjos LHC, Oliveira VA, Lumbreras JF, Coelho MR et al. Sistema brasileiro de classificação de solos. Brasília, DF: Embrapa SCT; 2013.

Schorn LA, Formento S. Silvicultura II: produção de mudas florestais. Blumenau: FURB; 2003.

Silva FC, Abreu MF, Pérez DV, Eira PA, Abreu CA, Raij B et al. Métodos de análises químicas para avaliação da fertilidade do solo. In: Silva FC, editor. Manual de análises químicas de solos, plantas e fertilizantes. 2nd ed. Brasília, DF: Embrapa Informações Tecnológica; 2009. p. 107184.

Steffen GPK, Antoniolli ZI, Steffen RB, Schiedeck G. Utilização de vermicomposto como substrato na produção de mudas de Eucalyptus grandis e Corymbia citriodora. Pesquisa Florestal Brasileira 2011; 31(66): 75-82. 10.4336/2011.pfb.31.66.75

Taiz L, Zeiger E, Moller IM, Murphy A. Fisiologia e desenvolvimento vegetal. 6th ed. Porto Alegre: Artmed; 2017.

Tedesco MJ, Gianello C, Bissani CA, Bohnen H, Volkweiss SJ. Análise de solo, plantas e outros materiais. Porto Alegre: Universidade Federal do Rio Grande do Sul; 1995.

Trazzi PA, Caldeira MVW, Passos RR, Gonçalves EO. Substratos de origem orgânica para produção de mudas de teca (Tectona grandis Linn. F.). Ciência Florestal 2013; 23(3): 401-409. 10.5902/1980509810551

Trigueiro RM, Guerrini IA. Utilização de lodo de esgoto na produção de mudas de aroeira-pimenteira. Revista Árvore 2014; 38(4): 657-665. 10.1590/S0100-67622014000400009

Vieira CR, Weber OLS, Scaramuzza JF. Influência do vermicomposto no crescimento e na nutrição de mudas de angico cascudo. Revista Biociências 2014; 20(2): 52-61.

Vivian MA, Modes KS, Beltrame R, Souza JT, Santini EJ, Haselein CR. Propriedades físico-mecânicas da madeira de canafístula aos 10 anos de idade. Ciência Rural 2010; 40(5): 1097- 1102. 10.1590/ S0103-84782010005000086

Wendling I, Dutra LF. Produção de mudas de eucalipto por sementes. In: Wendling I, Dutra LF. Produção de mudas de eucalipto. Colombo: Embrapa Florestas; 2010. p. 13-46. 